Short Communication

\title{
Response of Some Medicinal Plants to Vesicular Arbuscular Mycorrhizal Inoculations
}

\author{
B. Karthikeyan ${ }^{1}$, M. M. Joe ${ }^{1}$ and C.A. Jaleel ${ }^{2 *}$ \\ ${ }^{1}$ Department of Microbiology, Faculty of Agriculture, Annamalai University, Annamalainagar \\ 608 002, Tamilnadu, India \\ ${ }^{2}$ Stress Physiology Lab, Department of Botany, Annamalai University, Annamalainagar 608 002, \\ Tamilnadu, India
}

Received 4 December 2008, accepted in final revised form 27 February 2009

\begin{abstract}
An investigation has been made about the response of vesicular arbuscular mycorrhizal fungi of $G$. fasciculatum on some medicinal plants. Medicinal plants species selected for the study are Ocimum sanctum, Catharanthus roseus, Coleus forskholii and Cymbopogon flexuosus. The percentage of VAM association is 85 and the intensity of formation of vesicles and arbuscules are $70 \%$ and $30 \%$, respectively in VAM inoculated C. roseus plants. The total dry matter production (shoot and root dry wt), protein and total chlorophyll contents are seen to increase in VAM inoculated plants. The percentage of increase is more in C. roseus, followed by Cymbopogon flexosus when compared to control plants.
\end{abstract}

Keywords: Ocimum sanctum, Coleus forskholii, Cymbopogon flexosus, Catharanthus roseus, VAM fungi.

@ 2009 JSR Publications. ISSN: 2070-0237 (Print); 2070-0245 (Online). All rights reserved.

DOI: 10.3329/jsr.v1i2.1675

\section{Introduction}

The cultivation of medicinal and herbal plants has assumed greater importance in recent years due to their tremendous potential in modern and traditional medicine. They are also used as raw materials for pharmaceutical, cosmetic and fragrance industries. Indian system of medicine (ISM) uses 25,000 species belonging to more than 1000 genera. About 25\% species are used by the industries [1].

Inoculation of VAM fungi during an early stage of acclimatization process has become an alternative strategy for better establishment by improving the plant growth.

The occurrence of micro organisms especially VAM fungi on the medicinal plants have been reported earlier [2 - 4]. The VAM fungi association had not only enhanced the growth of medicinal plants but also improve the productivity of medicinal compounds.

\footnotetext{
*Corresponding author: abdul79jaleel@rediffmail.com
} 
Hence there is a need for research in improving the quality and quantity of drugs produced from native medicinal plants in relatively shorter period and at lower expense by using VAM fungi. Though there are reports on beneficial effects of VAM on other crops, a literature search reveals only a few reports on the VAM association with medicinal plants. In the present study, medicinal plants like thulsi (Ocimum sanctum), Periwinkle (Catharanthus roseus), Coleus (Coleus forskholii), and Lemon grass (Cymbopogon flexuosus) were selected for assessing their response to VAM fungus.

\section{Materials and Methods}

Pot culture experiments were conducted using natural un-sterilised soil. Four sets of eight pots were taken and each pot was filled with $5 \mathrm{~kg}$ soil. Three pots of each set were treated as inoculated by mixing $500 \mathrm{~g} /$ pot of pure cultures of $\mathrm{G}$. fasciculatum inoculum having 25 spores $/ 100 \mathrm{~g}$ of soil, and the other three were treated as control as there was no addition of VAM inoculum. Seedlings of medicinal plants were transplanted in both treated and untreated control pots. The plants were regularly watered once in three days. The plants at the time of flowering stage (150 days) were harvested along with their root system and roots were cleared by dipping them in water 2 to 3 times till the adhering soil particles were removed.

\subsection{Assessment of VAM association and its biomass estimation}

Few representative root samples from both treated and untreated plants were cut into $1 \mathrm{~cm}$ bits and fixed in a standard FAA (formalin acectoalcohol) and processed further for the assessment of VAM colonization (percentage mycorrhizal association) by staining [5].The plants were oven dried for $72 \mathrm{~h}$ at $70^{\circ} \mathrm{C}$ root and shoot systems were then weighed.

\subsection{Estimation of total chlorophyll}

One gram fresh leaf sample taken from each replication was analyzed for total chlorophyll content by following the method of Talling and Driver [6]. The fresh plant sample was ground with 95\% ethanol using pestle and mortar. The extract was allowed to settle in dark for $30 \mathrm{~min}$ at room temperature. The suspension was centrifuged at $5000 \mathrm{rpm}$ at room temperature for $10 \mathrm{~min}$. The supernatant was collected and the volume was made up to a known volume using 95 per ethanol. The absorbance was read at 665 and $649 \mathrm{~nm}$ in Beckmann DU 64 spectrometer against 95\% ethanol blank. The total chlorophyll was calculated using the formula:

Total chlorophyll $(\mu \mathrm{g} / \mathrm{g})=6.10(\mathrm{~A} 665)+20.04(\mathrm{~A} 649) \times V$

Here, A665 = Absorbance at 665nm, A649 = Absorbance at $649 \mathrm{~nm}$, and $V=$ volume of ethanol extract.

The chlorophyll content of the leaf sample was estimated and expressed as $\mathrm{mg} \mathrm{g}^{-1}$ fresh wt of sample. 


\subsection{Estimation of protein content}

Protein content of leaf samples was determined by the method developed by Bradford [7].

\subsubsection{Bradford reagent}

One hundred mg Coomassie Brilliant blue G250 was dissolved in $50 \mathrm{ml}$ of $95 \%$ ethanol and mixed with $100 \mathrm{ml}$ of concentrated phosphoric acid. The volume was made up to 200 $\mathrm{ml}$ with distilled water. The reagent was stored at $4^{\circ} \mathrm{C}$. This was diluted five times with distilled water prior to use.

Procedure:

One gram fresh leaf sample was extracted with $2 \mathrm{ml}$ of $0.1 \mathrm{M}$ phosphate buffer (pH 7.0). The extract was centrifuged at $5000 \mathrm{rpm}$ for $10 \mathrm{~min}$ at room temperature. To 0.1 of clear supernatant, $5.0 \mathrm{ml}$ of Bradford's reagent was added. The blue colour developed was red at $595 \mathrm{~nm}$ in Beckman DU 64 spectrophotometer. From the standard graph prepared using Bovin serum albumin over a concentration ranging from 1 to $100 \mu \mathrm{g} / \mathrm{ml}$, the protein concentration of leaf sample was estimated and expressed as $\mathrm{mg} / \mathrm{g}$ of fresh weight of sample.

\subsection{Statistical Analysis}

The experiment results (Table 1) were statistically analyzed in the Duncans multiple range test (DMRT) using SPSS 7.0 statistical package. The triplicate sets of data (Table 2) were subjected to ANOVA in accordance with Completely Randomized Block Design using NPRC statistical package to quantify and evaluate the source of variation. CD (Critical Differences) values were calculated at $P$ level of $0.05 \%$.

\section{Results and Discussion}

It is clearly evident from the data that the root systems of all medicinal plant species grown in both control and VAM fungus infested soils were invariably found to harbour VAM association. The plants grown in the soil without addition of VAM inoculum; recorded VAM association of 12 to $20 \%$ and the intensity of vesicles was 20 to $30 \%$ and arbuscules was 8 to $12 \%$. However, these results were found to be in significant (Table 1). In the inoculated plants, the percent VAM association (58 to 85\%) and vesicles (58 to $70 \%$ ), arbuscules (30 to $42 \%$ ) were highly significant (Table 1 ).

Among the four medicinal plants the maximum association of VAM was 85\% colonization and the intensity formation was 70 and 30\% for vesicles and arbuscules respectively in Catharanthus roseus plant. This was followed by $C$. flexuosus and $O$. sanctum. The minimum VAM association (58\% colonization) and intensity of $58 \%$ vesicles and $42 \%$ arbuscules were recorded in C. forskholii. Similarly, the shoot dry wt, root dry wt, protein content and the total chlorophyll content of the VAM inoculated plant 
was higher in C.roseus (25.22, $14.98 \mathrm{~g} /$ plant, 94.00 and $3.40 \mathrm{mg} / \mathrm{g}$ of plant) followed by C. flexousus and $O$. sanctum when compared to control plants.

Table 1. Intensity of VAM formation of some medicinal plants with Glomus fasciculatum.

\begin{tabular}{|c|c|c|c|c|c|c|}
\hline \multirow{4}{*}{ Plant } & \multicolumn{6}{|c|}{ VAM status } \\
\hline & \multicolumn{3}{|c|}{ Control plants } & \multicolumn{3}{|c|}{ VAM inoculated plants } \\
\hline & \multirow{2}{*}{$\begin{array}{c}\text { \% VAM } \\
\text { association }\end{array}$} & \multicolumn{2}{|c|}{ Intensity $\%$ of formation } & \multirow{2}{*}{$\begin{array}{c}\text { \% VAM } \\
\text { association }\end{array}$} & \multicolumn{2}{|c|}{ Intensity $\%$ of formation } \\
\hline & & vesicles & arbuscules & & vesicles & arbuscules \\
\hline Ocimum sanctum & $10 \pm 1.5$ & $12+0.75$ & $10 \pm 1.0$ & $65 \pm 1.0$ & $60+1.5$ & $40+2.0$ \\
\hline $\begin{array}{l}\text { Catharanthus } \\
\text { roseus }\end{array}$ & $20 \pm 1.5$ & $20+0.5$ & $12 \pm 0.5$ & $85+2.5$ & $70+1.5$ & $30+1.5$ \\
\hline Coleus forskholii & $12 \pm 0.5$ & $10 \pm 0.5$ & $8 \pm 1.5$ & $58+1.5$ & $58+1.5$ & $42+2.5$ \\
\hline $\begin{array}{l}\text { Cympbopogon } \\
\text { flexuosus }\end{array}$ & $15 \pm 1.0$ & $19 \pm 0.5$ & $11 \pm 0.5$ & $75 \pm 3.5$ & $65 \pm 1.5$ & $35 \pm 2.5$ \\
\hline
\end{tabular}

Values are mean of three replicates \pm SD.

It is clearly evident from the present study on the effect of VAM inoculation on mycorrhization and growth response in four selected medicinal plants (O. sanctum, $C$. roseus, C. forskholi, C. flexuosus) that these plants have readily responded to VAM inoculation, when grown in unsterile soil infested with G.fasciculatum inoculation. These results confirm the earlier reports by Bagyaraj and Manjunath [8] and Rao et al. [9].

Table. 2. Effect of G. fasciculatum inoculation on the shoot dry wt, root dry plant, protein content) and total chlorophyll content of some medicinal plants.

\begin{tabular}{|c|c|c|c|c|c|c|c|c|}
\hline \multirow[b]{3}{*}{ Plant } & \multicolumn{8}{|c|}{ VAM status } \\
\hline & \multicolumn{4}{|c|}{ Control Plants } & \multicolumn{4}{|c|}{ VAM inoculated plants } \\
\hline & $\begin{array}{l}\text { Shoot dry } \\
\text { wt(g/plant) }\end{array}$ & $\begin{array}{l}\text { Root dry } \\
\text { wt } \\
\text { (g/plant) }\end{array}$ & $\begin{array}{c}\text { PC } \\
\text { (mg/g of } \\
\text { plant) }\end{array}$ & $\begin{array}{l}\text { TCC } \\
\text { (mg/g } \\
\text { plant) }\end{array}$ & $\begin{array}{c}\text { Shoot dry } \\
\text { wt(g/plant) }\end{array}$ & $\begin{array}{c}\text { Root dry } \\
\text { wt(g/plant) }\end{array}$ & $\begin{array}{c}\mathrm{PC} \\
\text { (mg/g } \\
\text { plant) }\end{array}$ & $\begin{array}{c}\text { TCC } \\
\text { (mg/g plant) }\end{array}$ \\
\hline Ocimum & 12.44 & 7.64 & 60.40 & 1.20 & 18.44 & 11.04 & 80.20 & 2.20 \\
\hline $\begin{array}{l}\text { sanctum } \\
\text { Catharanthus }\end{array}$ & 15.66 & 8.44 & 70.66 & 1.90 & 25.22 & 14.98 & 94.00 & 3.40 \\
\hline $\begin{array}{l}\text { roseus } \\
\text { Coleus } \\
\text { forskholii }\end{array}$ & 8.00 & 5.66 & 53.40 & 1.00 & 15.91 & 10.00 & 79.27 & 1.96 \\
\hline $\begin{array}{l}\text { Cympbopogon } \\
\text { flexuosus }\end{array}$ & 13.00 & 8.00 & 65.20 & 1.50 & 20.10 & 15.20 & 84.00 & 2.60 \\
\hline $\mathrm{CD}(p=0.05)$ & 1.52 & 1.64 & 3.56 & 0.34 & 1.58 & 1.54 & 4.24 & 0.34 \\
\hline SD & 0.74 & 0.84 & 7.92 & 0.96 & 3.64 & 3.72 & 8.72 & 0.98 \\
\hline
\end{tabular}

PC - Protein content, TCC -Total chlorophyll content, CD - Critical differences, SD - Standard deviation.

The VAM colonization and growth response of $G$. fasciculatum was also observed in all the four medicinal plants (Tables 1, 2). All the four medicinal plants inoculated with 
VAM fungus have shown improved growth and development as compared to control plants. The control plants have VAM associations varying from 18 to 25\% (Table 1), when grown in un-sterilized soil due to low level natural inoculum. These results confirm the early reports by Bagyaraj and Manjunath [8]. The significant increase was observed not only in VAM colonization but also in biomass production (dry wt of root and shoot) due to inoculation with Glomus fasciculatum in all the four medicinal plants. The increased growth of treated plants due to mycorrhization of. G. fasciculatum (Table 1) and the above results are in conformity with those of Gupta and Janarthanan [10] and Earanna et al. [11].

Host plants growing in soils with relatively low nutritional level as in gulberga soil [12] are predisposed to effective endophytic fungal invasion [13]. In the present study, similar situation was observed in all the four medicinal plants, which recorded 58 to $75 \%$ VAM association (Table 1).

The root and shoot biomass (dry wt) of the inoculated plants were found to be maximum and significant than that of control in all the four medicinal plant species (Table 2). The reason may be due to the formation of external mycelium around the roots by VAM fungi. The results are in agreement with the findings of earlier work by Gupta and Janardhanam [10]. Basu and Srivatava [14] have earlier reported such enhanced growth in medicinal plant due to VAM fungal association. Similar improved growth response was also observed in 10 medicinal plants when inoculated with three VAM fungal species ( $G$. mossae, G. fasciculatum and G. monosporum) for their efficiency by Kumar and Murugesh [15]. They reported mycorrhizal inoculation was more advantageous in obtaining healthy vigorous seedlings and results in higher biomass of medicinal plants that were found to grow better in the field.

The inoculation with $G$. fasciculatum resulted in increased total chlorophyll content and protein content in all the four medicinal plants over control plant. The highest chlorophyll and protein content was recorded in C. roseus, followed by C. flexuosus, $O$. sanctum and $C$. forskholii. The increase in total chlorophyll content and protein content in inoculated plants may be due to increased uptake of phosphorus, which will increase the photosynthetic activity of the plants and ultimately the chlorophyll content in plants. Similar findings were reported already $[16,17]$. Thus the present study revealed the positive effect of $G$. fasciculatum on some medicinal plants.

\section{References}

1. C.A. Jaleel, R. Gopi, M. Gomathinayagam, and R. Panneerselvam, Process Biochemistry 44, 205 (2009). doi:10.1016/j.procbio.2008.10.012

2. C.A. Jaleel, P. Manivannan, B. Sankar, A. Kishorekumar, R. Gopi, R. Somasundaram, and R. Panneerselvam, Colloids Surf. B: Biointerfaces 60, 7 (2007). doi:10.1016/j.colsurfb.2007.05.012

3. C. A. Jaleel, R. Gopi, and R. Panneerselvam, Plant Omics J. 2, 30 (2009).

4. B. Karthikeyan, C. A. Jaleel, G. M. Alagu Lakshmanan, and M. Deiveekasundaram, Colloids Surf. B: Biointerfaces 62, 143 (2008). doi:10.1016/j.colsurfb.2007.09.004

5. J. M. Philips, D. S. Hayman, Trans. British Mycol. Soc. 55, 158 (1970). 
6. J. F. Talling and T. Driver, Proc. 10th Pacific Science Congress, University of Hawaii, US Atomoc Energy Commision (1961) pp. 142-146.

7. M. M Bradford, Anal. Biochem. 72, 248 (1976). doi:10.1016/0003-2697(76)90527-3

8. D. J. Bagyaraj, A. Manjunath, New phytol. 85, 33 (1980). doi:10.1111/j.1469-8137.1980.tb04445.x

9. Y. S. G. Rao, C. K. Suresh, N. S. Malikarjunah, and O. F. Bagyaraj, Indian Phytopathol. 92, 476 (1989).

10. M. L. Gupta and K. K. Janardhan, Plant Soil 131, 261 (1991). doi:10.1007/BF00009457

11. N. Earanna, R. R. Mallikarjunaiah, D. J. Bagyaraj, and C. K. Suresh, J. Species Arom. Crop 10, 141 (2001).

12. C. N. Reddy and G. R. Goud. Proceedings of first Asian conference of mycorrhizae (ACOM), Chennai, India. January 29 (1989).

13. E.W. Russell, ELBs and Longman: London, 849 (1975).

14. M. Basu and N. K. Srivastava. Indian phytopathol. 64, 110 (1998).

15. G. S. Kumar and S. Murugesh, Adv. Plant Sci. 15, 43 (2002).

16. S. Sitaramaih, K. R. Khanna, and N. Trimurthy, J. Mycol. Plant Pathol. 28, 38 (1998).

17. B. Karthikeyan, C. A. Jaleel, Z. Changxing, M. M. Joe, J. Srimannarayanan, and M. Deiveekasundaram, Eur Asia. J. Biosci. 2, 26 (2008). 